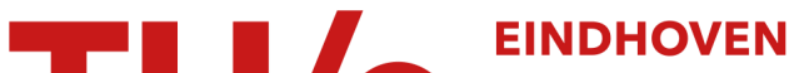 \\ UNIVERSITY OF \\ TECHNOLOGY
}

\section{Mössbauer study of carbon-supported alpha-iron catalysts}

\section{Citation for published version (APA):}

Christensen, P. H., Moerup, S., \& Niemantsverdriet, J. W. (1986). Mössbauer study of carbon-supported alphairon catalysts. Hyperfine Interactions, 28(1-4), 911-914. https://doi.org/10.1007/BF02061592

DOI:

10.1007/BF02061592

Document status and date:

Published: 01/01/1986

\section{Document Version:}

Publisher's PDF, also known as Version of Record (includes final page, issue and volume numbers)

\section{Please check the document version of this publication:}

- A submitted manuscript is the version of the article upon submission and before peer-review. There can be important differences between the submitted version and the official published version of record. People interested in the research are advised to contact the author for the final version of the publication, or visit the $\mathrm{DOI}$ to the publisher's website.

- The final author version and the galley proof are versions of the publication after peer review.

- The final published version features the final layout of the paper including the volume, issue and page numbers.

Link to publication

\section{General rights}

Copyright and moral rights for the publications made accessible in the public portal are retained by the authors and/or other copyright owners and it is a condition of accessing publications that users recognise and abide by the legal requirements associated with these rights.

- Users may download and print one copy of any publication from the public portal for the purpose of private study or research.

- You may not further distribute the material or use it for any profit-making activity or commercial gain

- You may freely distribute the URL identifying the publication in the public portal.

If the publication is distributed under the terms of Article 25fa of the Dutch Copyright Act, indicated by the "Taverne" license above, please follow below link for the End User Agreement:

www.tue.nl/taverne

Take down policy

If you believe that this document breaches copyright please contact us at:

openaccess@tue.nl

providing details and we will investigate your claim. 


\title{
MÖSSBAUER STUDY OF CARBON-SUPPORTED $\alpha$-Fe CATALYSTS
}

\author{
P.H. CHRISTENSEN and S. MORUP \\ Laboratory of Applied Physics II, Technical University of Denmark, DK-2800 Lyngby, \\ Denmark
}

\begin{abstract}
J.W. NIEMANTSVERDRIET
Laboratory of Inorganic Chemistry, Eindhoven University of Technology, $5600 \mathrm{MB}$ Eindhoven, The Netherlands

Mössbauer spectra of carefully reduced carbon-supported iron catalysts show superparamagnetic $\alpha-\mathrm{Fe}$ at $80 \mathrm{~K}$. The results indicate that the particle size depends on the reduction temperature. Effects of evacuation and $\mathrm{CO}$ chemisorption are discussed.
\end{abstract}

\section{INTRODUCTION}

Recently, Jung et al. /1/ have reported that very small particles of metallic iron $(\alpha-\mathrm{Fe})$ with diameters in the $2-3 \mathrm{~nm}$ range can be prepared on a carbon support called carbolac-l (c-l). Mössbauer spectra of these samples measured by Niemantsverdriet et al. confirmed that most of the iron is in the metallic state and revealed that about 60 of of the $\alpha-F e$ is superparamagnetic at $80 \mathrm{~K} / 2 /$.

In a subsequent study /3/ we have prepared an $\mathrm{Fe} / \mathrm{C}-1$ catalyst in which all $\alpha-F e$ is superparamagnetic at $80 \mathrm{~K}$ and we have estimated the average particle diameter by means of the magnetic field dependence of the Mössbauer spectra.

In this paper we show that the superparamagnetic behaviour of the $\alpha-F e$ particles depends critically on the reduction conditions. Spectra of the catalysts in $\mathrm{H}_{2}$, vacuum and $\mathrm{CO}$ show that the Mössbauer spectra are sensitive to the environment.

\section{EXPERIMENTAL SECTION}

The $\mathrm{Fe} / \mathrm{C}-1$ catalysts were prepared by the incipient wetness impregnation, as described earlier /3/. The samples were reduced in flowing hydrogen either at $725 \mathrm{~K}$ for $16 \mathrm{~h}$ or, in a two-step procedure, at $615 \mathrm{~K}$ for $16 \mathrm{~h}$ and at $675 \mathrm{~K}$ for $16 \mathrm{~h}$. During the measurements the samples were kept in an in situ Mössbauer cell, which allows spectra to be obtained at temperatures between $80 \mathrm{~K}$ and $725 \mathrm{~K}$ with applied magnetic fields up to about $1.0 \mathrm{~T} / 4 /$.

Mössbauer spectra were measured with a constant acceleration spectrometer. Velocities are given with respect to the isomer shift of $\alpha-\mathrm{Fe}$ at room temperature.

\section{RESULTS AND DISCUSSION}

Figure 1 shows the $80 \mathrm{~K}$ spectra of the catalyst after reduction at $675 \mathrm{~K}$. The spectra were obtained in hydrogen and in vacuum after desorption of hydrogen at $510 \mathrm{~K}$. Spectra of this sample measured in applied magnetic fields up to $1.0 \mathrm{~T}$ confirmed that the single peak is due to superparamagnetic $\alpha-F e$, and, furthermore that the average diameter of the particles is $2.5 \pm 0.2 \mathrm{~nm} / 3 /$.

The lines in the spectra shown in Fig. 1 , are rather broad, but the line width decreases when hydrogen is removed, indicating an 
increase in the superparamagnetic relaxation frequency. In accordance with previous studies of chemisorption on $\alpha-F e$ particles $/ 5,6 /$ we attribute this effect to an increase in the surface contribution to the magnetic anisotropy energy constant when hydrogen is chemisorbed on the surface of the particles.

The spectra of Fig. I contain, in addition to the singlet due to superparamagnetic $\alpha-\mathrm{Fe}$, a shoulder at about $2 \mathrm{mms}^{-1}$, which is attributed to unreduced iron in the ferrous state $/ 2 /$.

Figure 2 shows the $80 \mathrm{~K}$ spectra of the $\mathrm{Fe} / \mathrm{C}-1$ catalyst in vacuum and after $c o$ chemisorption at $190 \mathrm{~K}$, measured in an applied magnetic field of $1.03 \mathrm{~T}$. As a result of $\mathrm{CO}$ adsorption the sixtuplet is reduced in intensity and the relative area of the line at about $-0.2 \mathrm{mms}^{-1}$ has increased. Although a detailed interpretation is not yet possible, we believe that the changes in the spectrum are indicative of a strong interaction between $\mathrm{CO}$ and the iron atoms at the surface.

Figure 3 shows the room temperature spectrum of the $\mathrm{Fe} / \mathrm{C}-1$ catalyst after the first reduction step at $615 \mathrm{~K}$ measured in a $1 \mathrm{~T}$ field, and the spectrum after reduction at $675 \mathrm{~K}$ in a $0.55 \mathrm{~T}$ field. The relative area of the paramagnetic component is larger after reduction at $615 \mathrm{~K}$ than after reduction at $675 \mathrm{~K}$. Both spectra are partly magnetically split due to the applied magnetic fields, and the total widths of the superparamagnetic components are quite similar. Since the applied fields differ by a factor of about two we conclude that the volumes also differ by a factor of approximately two. Thus the mean diameter of the particles, prepared by reduction at $615 \mathrm{~K}$, is about $2.0 \mathrm{~nm}$.

Figure 4 shows spectra of the sample which was reduced at $725 \mathrm{~K}$. The spectrum obtained at $300 \mathrm{~K}$ in an applied magnetic field of 1.03 $T$ shows that about 50 of of the iron is $\alpha-F e$. The remaining iron is

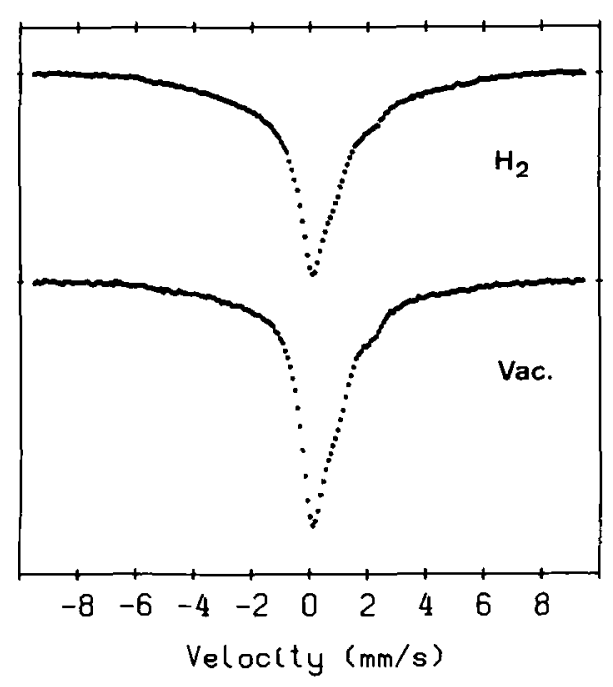

Fig.1. Mössbauer spectra obtained at $80 \mathrm{~K}$ of the $\mathrm{Fe} / \mathrm{C}-1$ catalyst after reduction in $\mathrm{H}_{2}$ at $675 \mathrm{~K}$ for $16 \mathrm{~h}$, and in vacuum after desorption of the $\mathrm{H}_{2}$ at $510 \mathrm{~K}$.

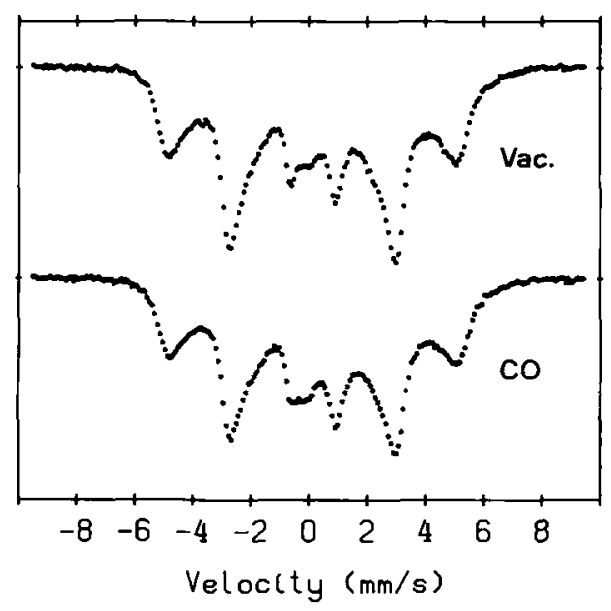

Fig.2. Mössbauer spectra of the $\mathrm{Fe} / \mathrm{C}-1$ catalyst after reduction at $625 \mathrm{~K}$. The spectra were obtained at $80 \mathrm{~K}$ in an applied magnetic field of $1.03 \mathrm{~T}$ in vacuum after evacuation at $510 \mathrm{~K}$ and after chemisorption of $\mathrm{CO}$ at $190 \mathrm{~K}$. 
present in iron carbides, possibly $\mathrm{Fe}_{\mathrm{X}} \mathrm{C}$ and $\mathrm{X}-\mathrm{Fe}_{5} \mathrm{C}_{2} / 7 /$. The $650 \mathrm{~K}$ spectra contain, in addition to the $\alpha-F e$ sextet, a singlet, in agreement with $x-\mathrm{Fe}_{5} \mathrm{C}_{2}$ being paramagnetic above $530 \mathrm{~K}$ $17 /$.

'ine spectrum, obtained at $300 \mathrm{~K}$ in an applied magnetic field of $0.01 \mathrm{~T}$ has broader lines than the $1.03 \mathrm{~T}$ spectrum and, moreover, a broad central line is present near zero velocity. These features can be explained by the presence of superparamagnetic relaxation effects and collective magnetic excitations /6,8/. A comparison with the spectra shown in Fig. 1 shows that reduction at $725 \mathrm{~K}$ leads to a considerably longer relaxation time than reduction at $675 \mathrm{~K}$. The results can be explained by an increase in the average diameter to about $10 \mathrm{~nm}$ upon reduction at $725 \mathrm{~K}$. It is, however, also possible that the better resolved magnetic hyperfine splitting in the room temperature spectra in Figure 4 can be explained by an enhancement of the magnetic dipole-dipole interaction between the particles $/ 2,9 /$.

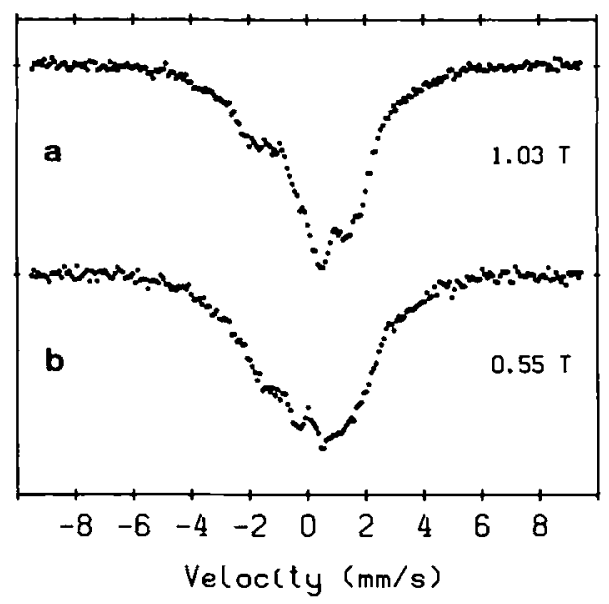

Fig.3. Room temperature Mössbauer spectra of the $\mathrm{Fe} / \mathrm{C}-1$ catalyst after

a) reduction at $615 \mathrm{~K}$ measured in $1.03 \mathrm{~T}$ applied magnetic field and

b) after reduction at $675 \mathrm{~K}$ measured in $0.55 \mathrm{~T}$ applied magnetic field.

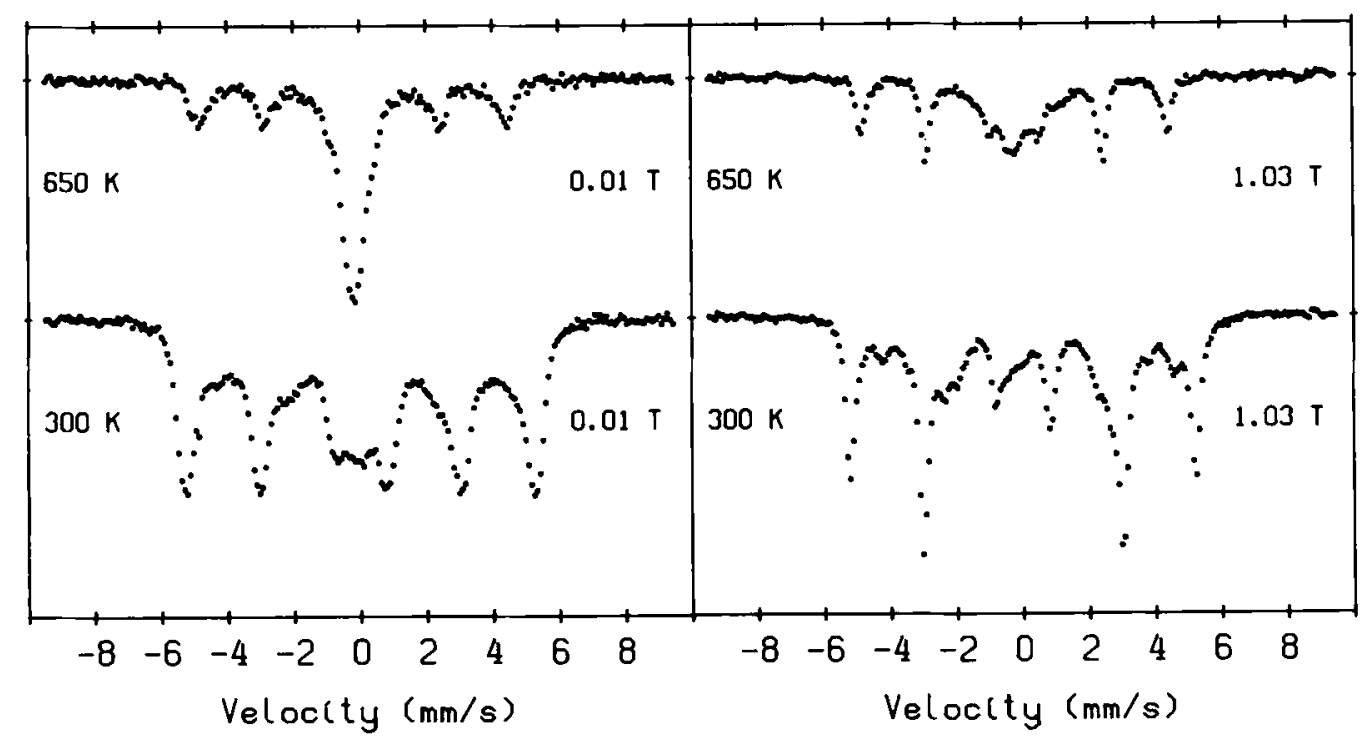

Fig.4. Mōssbauer spectra of the Fe/C-1 catalyst after reduction at $725 \mathrm{~K}$. Left: without applied magnetic field; right: with 1 T applied magnetic field. Upper spectra obtained at $650 \mathrm{~K}$ and lower spectra obtained at $300 \mathrm{~K}$. 
The carburization of the iron, seen from the presence of carbides in Fig. 4, is presumably due to the fact that C-I is significantly gasified in $\mathrm{H}_{2}$ above about $675 \mathrm{~K} / 10 /$. During the gasification $\mathrm{CH}_{4}$ is formed and these molecules act as carburizing agents for $\alpha-\mathrm{Fe}$.

\section{CONCLUSIONS}

The present study has shown that careful drying and reduction of carbon-supported iron catalysts results in formation of very small $\alpha-F e$ particles, which are well suited for studies of surface effects.

The particle size seems to increase with increasing reduction temperature and carbide formation becomes important at reduction temperatures above $675 \mathrm{~K}$.

\section{ACKNOWLEDGEMENTS}

The authors acknowledge support from the Netherlands Organization for the Advancement of Pure Research (Z.W.O.) and the Danish Council for Scientific and Industrial Research.

\section{References}

/ 1/ H.J. Jung, M.A. Vannice, L.N. Mulay, R.M. Stanfield, W.N. Delgass, J. Catal. 76 (1982) 208.

/ $2 /$ J.W. Niemantsverdriet, A.M. van der Kraan, W.N. Delgass, M.A. Vannice, J. Phys. Chem. 89 (1985) 67.

/ $3 /$ P.H. Christensen, S. Mørup and J.W. Niemantsverdriet, J. Phys. Chem. (in Press).

/ $4 /$ B.S. Clausen, S. Mørup, P. Nielsen, N. Thrane and H. Topsøe, J. Phys. E: Sci. Instrum. 12 (1979) 439.

/ 5/ S. Mørup, B.S. Clausen and H. Topsфe, J. Physique Colloq. 41 (1979) Cl-331.

/ 6/ S. Mørup, H. Topsфe, B.S. Clausen, Phys. Scripta, 25 (1982) 713.

/ $7 /$ J.W. Niemantsverdriet, A.M. van der Kraan, W.L. van Dijk, and H.J. van der Baan, J. Phys. Chem. 84 (1980) 3363.

/ 8/ S. Mørup, J.A. Dumesic and H. Topsøe, in Applications of Mössbauer Spectroscopy, Vol. II, ed. R.I. Cohen (Academic Press, New York, 1980), p.I.

/ 9 / S. Mørup, J. Magn. Magn. Mat. 37 (1983) 39.

/10/ M.A. Vannice, Personal communication. 